\title{
Demand and Distance: Evidence on Cross-Border Shopping*
}

\author{
Marcus Asplund \\ London Business School and CEPR \\ Richard Friberg \\ Stockholm School of Economics and CEPR \\ Fredrik Wilander \\ Stockholm School of Economics \\ SSE/EFI Working Paper Series in Economics and Finance \\ No 587
}

February, 2005

\begin{abstract}
While many studies have documented deviations from the Law of One Price in international settings, evidence is scarce on the extent to which consumers take advantage of price differentials and engage in cross border shopping. We use data from 287 Swedish municipalities to estimate how responsive alcohol sales are to foreign prices, and relate the sensitivity to the location's distance to the border. Typical results suggest that the elasticity with respect to the foreign price is around 0.4 in the border region; moving 200 (400) kilometers inland reduces it to $0.2(0.1)$. Given that cross country price differences for alcohol and other products are often caused by taxes, our evidence has implications for the debate on tax competition/harmonization.
\end{abstract}

Keywords: Law of one price, tax competition, tax harmonization, cross border shopping, European integration.

JEL Codes: F15, H20, H77, R12

\footnotetext{
* We thank Peter Davis, Raphael Thomadsen, and seminar participants at the 2005 ENTER Jamboree in Brussels for valuable comments. Anna Ihrfors Wikström at Systembolaget provided the data. Financial support from Vetenskapsrådet (Friberg) and Bankforskningsinstitutet (Wilander) is gratefully acknowledged.

^ Corresponding author, Stockholm School of Economics, PO Box 6501, SE-113 83 Stockholm, Sweden. Tel: +46-8-736 9602, fax: +46-8-31 3207 e-mail:nerf@hhs.se.
} 


\section{Introduction}

That prices of many goods differ considerably across countries is well documented. ${ }^{1}$ What we know much less about, however, is to what extent consumers actually take advantage of these price differentials and engage in cross border arbitrage. To provide evidence on this, we examine the responsiveness of alcohol sales in Swedish communities to foreign prices, and relate the price sensitivity to a location's distance to the border.

With the deeper integration of the European Union (EU) and its expansion, the effects of cross border trade has become an important policy issue as in many cases the price differences are due to taxes set by individual member states. The resulting price differentials may be so great that consumers in high tax countries do their purchases elsewhere, with important consequences for tax revenues. In fact, it is sometimes argued that countries "compete" by lowering taxes to attract foreign demand leading to an equilibrium with taxes at a lower level than if countries had been able to coordinate; see for instance Kanbur and Keen (1993). ${ }^{2}$ These issues figure prominently in the ongoing debate on tax harmonization within the EU and can be illustrated with the following quote from a press release regarding taxes on alcohol. $^{3}$

"The Commission concludes that more convergence of the rates of excise duty [on alcohol] in the different Member States is needed so as to reduce distortions of competition and fraud. However, given the widely differing views in the Member States about the appropriate levels of the minimum rates, and given that any change would require

\footnotetext{
${ }^{1}$ See for instance Engel and Rogers (1996), Goldberg and Knetter (1997), Haskel and Wolf (2001), Anderson and Van Wincoop (2004), Goldberg and Verboven (2005).

2 Theoretical work using a game theoretic framework was pioneered by Mintz and Tulkens (1986). Kanbur and Keen (1993) examine a tax setting game between two governments. In their model consumers incur a transport cost to shop in the other country such that the closer to the border they live, the less costly is it to go shopping abroad. In their analysis a less densely populated country will set the lower tax rate since it has relatively less to loose from lowering taxes. Wang (1999) shows that this result from Kanbur and Keen is further strengthened if the large country decides on tax first. Nielsen (2001) let countries differ in size rather than in population density, and similarly finds that the smaller country sets the lower tax rate; see Keen (2002) for a survey.

${ }^{3}$ Some recent cuts in alcohol taxation by Denmark (October 2003) and Finland (March 2004) were prompted by concerns over cross border shopping from Germany and Estonia, respectively. This, in turn, caused Sweden to consider the effects of reducing its taxes to limit the price differential with neighbouring Denmark and Finland (SOU, 2004). Britain was recently sued by the European Commission (October 2004) on claims that it tried to hinder high volume cross border shoppers of alcohol in a way that is inconsistent with the common market.
} 
unanimous agreement, the Commission is not making a proposal at this time. Instead the Commission wishes to launch a broad debate in the Council, the European Parliament,..." (Press release May 26, 2004).

A key problem in this debate is that little is known about the magnitude of cross border shopping, see Keen (2002) for a discussion. Interview studies indicate that the effects might be substantial. Frequently cited work by Fitzgerald (1992) for instance reports that in 1986 about 25 percent of spirits bought in the Republic of Ireland were bought in Northern Ireland. Campbell and Lapham (2004) examine links between the number of firms along the Canada-US border and the real exchange rate. They find that when prices in the US fall relative to prices in Canada (a real exchange rate depreciation) there is a significant increase in the number of sellers and/or in the average employment on the US side of the border for the four industries they study (food stores, gasoline service stations, drinking and eating places). Their findings are thus consistent with substantial changes in demand as a result of relative price changes and therefore with substantial cross border flows. However, based on an interview study by Ford (1992), they argue that for the industries in question the effects of cross border shopping are confined to border counties. Goldberg and Verboven (2005) report that, despite persistent price differences, cross border shopping of automobiles in Europe is limited. There also exist some papers that examine spillover effects of different sales taxes across US states (see e.g. Fox, 1986, and Walsh and Jones, 1988). ${ }^{4}$ This literature suggests that low prices across the border are important for sales in the border counties but it is an open question whether this also has an effect on the interior.

An unusually ambitious interview study by the Centre for Social Research on Alcohol and Drugs provides an indication of the extent of cross border shopping of alcohol. Since 2001, about 18000 randomly selected Swedes per year have been asked about their consumption of alcohol, and also the sources. Figure 1, which is based on data in Table 6.1 in SoRAD (2004), shows the consumption in 2003 from the three main sources of alcohol consumption (the Swedish government retail monopoly,

\footnotetext{
${ }^{4}$ A related literature examines the revenue impact at the state level of taxes in neighbouring states. This literature shows that cross border shopping acts as a constraint on the possibilities to raise state revenue by sales taxes, gasoline taxes or state lotteries. See Garrett and Marsh (2002) for references. Similarly, Beard et al (1997) try to infer the amount of cross border shopping from state level data on alcohol sales. Another somewhat related paper is Goolsbee (2000) who documents more Internet sales in high sales tax locations.
} 
legally imported, illegally imported), measured in liter of pure alcohol. ${ }^{5}$ The data is disaggregated by seven regions. As discussed below, the gateway to lower alcohol prices is in Sweden's south western corner and we measure each region's average distance to Malmö. Bearing in mind the problem with measurement errors ${ }^{6}$ with this type of data, the general picture that emerges is that the fraction of imported alcohol is negatively related to the distance to the border. There is, however, only a weak tendency of a negative relationship between the distance and the sum of the three sources. This aggregate data suggests that the prevalence of cross border shopping is related to the distance to the border and that it is roughly replacing domestic sales. However, even with this type of data, a more quantitative analysis is needed in order to disentangle the relationship between demand at the local level, domestic and foreign prices, and distance to the border.

\section{[FIGURE 1 ABOUT HERE]}

\section{[FIGURE 2 ABOUT HERE]}

In this paper we use data from the Swedish government retail monopoly to estimate how the sensitivity of sales to foreign prices depends on the distance to the border. A number of features make this an unusually clean case. First, we have monthly data on sales of spirits, wine, and beer over a ten year period for each store that sells alcohol in Sweden. Second, prices are the same across the country. This implies that prices in border areas are not endogenously lower, which in other cases could blur the picture. At the same time, relative prices between countries have varied considerably due both to major tax changes and volatile exchange rates. Third, as seen in the Figure 2, geography suggests that it is easy to measure the distance to the relevant Danish border. The shape of the country (from north to south it is a drive of about 2000 kilometers or 24 straight hours) also gives us substantial variation to exploit.

Our findings suggest that distance to the border plays an important role for the extent of cross border arbitrage. Using our estimates from spirits, in a border region

\footnotetext{
${ }^{5}$ For ease of comparison, we have excluded consumption a) at restaurants and pubs b) of beer and ciders with low alcohol content that can be bought outside Systembolaget, and c) of homemade alcoholic beverages.

${ }^{6}$ The telephone interviews underestimate the true consumption, due primarily to peoples' systematic underreporting of their own consumption (see www.sorad.su.se/alkrapp.pdf). SoRAD has attempted to correct for this in the numbers we use for Figure 2.
} 
the demand elasticity with respect to the foreign price is about 0.4 while moving 200 kilometers inland this elasticity is reduced to 0.2 ; at 400 kilometers the elasticity is 0.1 .

\section{Data}

The government owned retail monopoly (Systembolaget) made available monthly volume data on sales of spirits, wine, and beer at all its approximately 600 outlets. For the regressions we aggregate the data and use variation in per capita sales across 287 Swedish municipalities over the period January 1995 - July 2004 to estimate demand functions. A great advantage with data from Systembolaget is that it is required to keep the same prices and assortment in all stores (at smaller outlets the customer needs to order some products in advance), which implies that prices are not influenced by local demand conditions.

To measure the development of prices, we use price indices from Eurostat for the different product categories ${ }^{7}$. Foreign price indices are converted to Swedish kronor by the corresponding monthly average exchange rate. All prices are deflated by the Swedish Consumer Price Index. Figures 3a-3c show the development of aggregate sales, as well as Swedish and Danish price indices, for the three product categories. Although there is a great deal of seasonal variation, the broad trends with increasing sales of beer and wine, and a steady decline of spirits, are clearly visible. The most drastic price movements are due to tax changes in Sweden (January 1997 for beer and December 2001 for wine) and Denmark (October 2003 for spirits). The floating exchange rate between Swedish kronor and Danish kronor contributes to the comparatively high volatility of the Danish prices when expressed in Swedish kronor.

[FIGURES 3a-3c ABOUT HERE]

\footnotetext{
${ }^{7}$ We use the Harmonized Consumer Price Indices obtained from the Eurostat database for spirits (cp0211), wine (cp0212) and beer (cp0213). These are monthly indices available for all individual member countries.
} 
The prices are indices and thus do not inform us about differences in the level of prices between countries. However, Horverak and Osterberg (2002) gives us a snapshot, as of June 1999, of the prices of identical baskets in Denmark and Sweden. At that time a basket with beer was 27 percent cheaper and the spirits basket was 10 percent cheaper in Denmark; the basket with wine was 1.5 percent more expensive. We have normalized the price indices in Figures 3a-3c to reflect the difference at this date. While the compositions of these baskets certainly differ from those that form the basis of the price indices, this nevertheless suggest that over essentially the whole time period spirits are cheaper in Denmark, wines are at least as expensive as in Sweden, and beer much cheaper in Denmark.

Another way of examining the price levels comes from the Purchasing Power Parity indices of alcoholic beverages that Eurostat calculates on a yearly basis. For each year the average price for the EU-15 is $100 .^{8}$ The average of this index over 1995-2003 was 235 for Norway, 188 for Finland, 162 for Sweden, 129 for Denmark and 83 for Germany. Thus, on average a basket of alcohol was some 25 percent more expensive in Sweden than in Denmark, and almost twice as expensive as in Germany. The levels obviously differ over the years but the ranking is consistent. To avoid the influence of Norwegian and Finnish cross border shoppers, we exclude all Swedish municipalities that border Norway or Finland in our regressions. However, we report separate regressions to illustrate the effects in the northern regions when Finland drastically cut the tax on spirits in March 2004.

When Sweden joined the European Union in January 1995 it agreed to gradually loosen the restrictions on the alcohol that could be brought in from other member countries. From December 1994 to July 2004 the legal quota had increased from 1 liter of spirits, 1 liter of wine, and 2 liters of beer to 10 liters of spirits, 90 liters of wine and 110 liters of beer. (The 1994 quotas applied to imports from outside EU throughout the period.) The main gateway to lower alcohol prices is in Sweden's south-west corner (see Figure 2). To Denmark there are quick ferries from Helsingborg, and in July 2000 a toll bridge was opened linking Malmö to Copenhagen, Denmark (before this there were quick ferries linking the two cities). To

\footnotetext{
${ }^{8}$ We use the series for alcohol, "A010201" from the database "Purchasing power parities (PPP) and comparative price level indices for the ESA95 aggregates".
} 
Germany, there are a number of ferry lines from Trelleborg. ${ }^{9,}{ }^{10}$ Our main measure of distance to the border is kilometers by car (by the fastest route) to Malmö; Malmö, Helsingborg, and Trelleborg are very closely situated and the correlation between distance measures to these locations will be very close to one.

In Figure 4 we relate the change in per capita sales between May 1995 and May 2004 to the distance to the Malmö. The figures show a striking upward sloping relation between the distance from the border and the growth in sales. ${ }^{11}$ The regression lines indicate that there is a concave relation between sales growth and distance (results in Table 1). In regressions (not reported) this concave relation was robust to the inclusion of disposable income at the municipality level (data only available until 2002). The relation was also robust to the exclusion of the more northerly ferry ports (Helsingborg, Göteborg and Varberg) and their surrounding municipalities - a finding consistent with our assumption that the Malmö-Trelleborg area was the main gateway.

[FIGURE 4 ABOUT HERE]

[TABLE 1 ABOUT HERE]

\section{Econometric model}

That distance to the border seemed to play a role for the development of a region's alcohol sales was shown above. In this section we estimate how sensitive regional sales are to the price across the border, $\mathrm{P}^{\mathrm{F}}$, and the domestic price, $\mathrm{P}^{\mathrm{D}} \cdot{ }^{12}$

\footnotetext{
${ }^{9}$ For the different alternatives, the distance in hours (one way) and prices per car with same day return in 2004 were in Swedish kronor (kr) (9kr 1Euro): Malmö-Denmark (bridge) 15minutes, 500kr; Helsingborg-Denmark 20min, 580kr; Trelleborg-Germany 4hours, 650kr. There are also infrequent ferries to Denmark further north: Varberg-Denmark 4 hours, 1195kr and Göteborg-Denmark 3 hours, $745 \mathrm{kr}$.

${ }^{10}$ When Poland and the Baltic States joined the European Union in May 12004 additional low price locations became accessible. However, Poland is 8 hours from Ystad (south of Malmö) and Estonia is 15 hours from Stockholm and we have not tried to measure the impact of these improved opportunities to buy cheap alcohol.

${ }^{11}$ There is one particularly large positive outlier close to the border - the municipality of Kävlinge (population 25000). Closer examination of the data shows that a new store was opened right next to the major highway along Sweden's west coast, attracting consumers from other areas. This new store also explains the sharp fall in the neighbouring municipality of Svalöv (population 10000).

${ }^{12}$ Demand can in principle be modelled as dependent on prices in several neighbouring countries. In our application, however, the fact that the distances to Denmark and Germany are virtually the same gives rise to a severe multicollinearity problem that we are not able to address with the relatively short time dimension in the data. As a consequence we run separate regressions Danish and German price.
} 
The starting point is that demand per capita for alcohol of type $\mathrm{j}=\{$ spirits, wine, beer $\}$ in region $\mathrm{i}$ at time $\mathrm{t}$ is given by

$$
\ln \left[q_{j, i, t}\right]=b_{j, 0}+b_{j, 1} \ln \left[P_{j, t}^{D}\right]+g\left(\boldsymbol{d}_{j}, D_{i}\right) \ln \left[P_{j, t}^{F}\right]+\boldsymbol{\beta} \boldsymbol{X}_{j, i, t}+u_{j, i}+e_{j, i, t}
$$

where $\mathbf{X}$ is a vector of other variables, $\mathrm{u}$ is unobserved heterogeneity, and e is a standard error term. The own price elasticity is $b_{1}$. The elasticity with respect to the foreign price is $\mathrm{g}(\mathbf{d}, \mathrm{D})$ and thus depends on the distance to the border, D (in 1000 kilometers); $\mathbf{d}$ is a vector of parameters to be estimated. The prior is that the influence of the foreign price is decreasing in the distance to the border such that $\mathrm{g}^{\prime}(\mathbf{d}, \mathrm{D})<0$ and $g$ '” $(\mathbf{d}, \mathrm{D})>0$. We specify the function $\mathrm{g}(.,$.$) as a flexible third order polynomial { }^{13}$

$$
g\left(\boldsymbol{d}_{\boldsymbol{j}}, D_{i}\right)=d_{j, 0}+d_{j, 1} \times D_{i}+d_{j, 2} \times D_{i}^{2}+d_{j, 3} \times D_{i}^{3} .
$$

Regions differ not only in consumption levels but may also differ in the seasonal purchasing patterns. The first type of heterogeneity is captured by $\mathrm{u}_{\mathrm{j}, \mathrm{i}}$ in (1), while the second would be captured in $\mathbf{X}_{\mathbf{j}, \mathbf{i , t}}$ by region specific dummy variables for each calendar month. We use 12-month differences, $\Delta_{12}$, to take out these region specific effects and estimate

$$
\Delta_{12} \ln \left[q_{j, i, t}\right]=b_{j, 0}+b_{j, 1} \Delta_{12} \ln \left[P_{j, t}^{D}\right]+\left(d_{j, 0}+d_{j, 1} D_{i}+d_{j, 2} D_{i}^{2}+d_{j, 3} D_{i}^{3}\right) \Delta_{12} \ln \left[P_{j, t}^{F}\right]+\Delta_{12} \boldsymbol{\beta} \boldsymbol{X}_{t}+\varepsilon_{j, i, t}
$$

In (2) we have omitted the subscripts $\mathrm{j}$ and $\mathrm{i}$ on $\mathbf{X}_{\mathbf{t}}$ to emphasize that it includes no region or type specific variables. The only variable in $\mathbf{X}_{\mathbf{t}}$ is the log of the number of Fridays in the month (four or five), to capture that traditionally most of the sales are on Fridays (until 2003, outlets were closed on Saturdays and Sundays).

We estimate (2) as a system of seemingly unrelated equations (SUR) to account for the fact that error terms are correlated (correlation of 0.6-0.8) across equations but treating $\Delta_{12} \ln \left[P_{j, t}^{D}\right]$ and $\Delta_{12} \ln \left[P_{j, t}^{F}\right]$ as uncorrelated with the error terms. The reason for assuming that $\Delta_{12} \ln \left[P_{j, t}^{F}\right]$ is predetermined is that the national price

\footnotetext{
${ }^{13}$ This is analogous to a parametric version of the model of Pinkse et al (2002).
} 
indices of Denmark and Germany are unlikely to be influenced by local Swedish demand shocks. ${ }^{14}$ The institutional fact that prices do not vary across Swedish locations and that changing taxes is a very drawn out process are two reasons for why endogeneity of $\Delta_{12} \ln \left[P_{j, t}^{D}\right]$ is not an issue here. ${ }^{15}$

\section{Results}

In the regressions below, we exclude municipalities that border to Norway or Finland. We also report results for the subsample where March and April months are excluded, since sales are greatly influenced by which month Easter falls. We also use a subsample where, in addition, all municipalities more than 1000 kilometers away from Denmark and Germany are excluded.

\section{[TABLE 2 ABOUT HERE]}

\section{[TABLE 3 ABOUT HERE]}

The results when the foreign price is defined as the price in Denmark and Germany for the three categories are shown in Table 2 and Table 3, respectively. Overall, coefficients are significant with the expected signs and are plausible in magnitude. The effects on demand of changes in foreign prices are quite similar for the two price indices. One might have expected the effect of German prices to be weaker, since it is more costly to go there both in terms of time and outlays. However a counteracting influence may be that German prices are substantially lower than Danish prices. For some consumers, who buy large quantities, the extra distance associated with shopping in Germany rather than in Denmark will be worthwhile. Instead of focusing on any particular coefficient, we use Figures $5 \mathrm{a}-5 \mathrm{c}$ to illustrate the effect of a

\footnotetext{
${ }^{14}$ Given the population sizes of the countries (Denmark, $5.4 \mathrm{~m}$, and Germany, $82.8 \mathrm{~m}$ ) it is unlikely that national prices are influenced by demand from Swedish cross border shoppers. The fact that $\mathrm{P}^{\mathrm{F}}$ is a national average does in itself not rule out the possibility prices just across the border are influenced by local Swedish demand shocks. However, since Copenhagen with a population of 1.7 million is the border town this suggests that changes in prices there are driven by changes in Danish rather than Swedish conditions. The argument also applies to the local prices in Germany.

${ }^{15}$ For instance, in response to concerns about cross border arbitrage following the Danish tax cut in October 2003, a government commission was initiated in January 2004. As of February 2005, their recommendations are still under review and various interested parties can still influence the outcome. Before any new taxes will come into effect, the final proposal will first have to pass parliament and be written into law, something that might take at least another year.
} 
hypothetical 10 percent reduction in the price of Danish spirits, wine and beer, respectively. A 10 percent reduction in the Danish price of spirits causes a fall in per capita sales of roughly 4 percent at the border (Malmö). This large cross price elasticity is almost half the own price elasticity. As seen the effect of the tax-cut diminishes gradually as one moves further from the border. The fall in sales is estimated to drop below 1 percent only at 460 kilometer from the border and not until we reach 1000 kilometers can we reject that the effect is zero.

\section{[FIGURES 5a-5c ABOUT HERE]}

For beer the effects again disappear around 1000 kilometers, while for wine the effect tapers off much more rapidly, reaching zero at some 200 kilometers from the border. A likely explanation for this difference is that prices of beer are significantly lower across the border while prices of most medium to high quality wines are about the same. However, in Demark there exist low quality wines that are cheaper than any that can be found in Sweden. This could give rise to modest amounts of cross border shopping.

Overall, it might be surprising that effects may stretch this far from the border. Note though that these products are easily transported and storable - by driving down to Denmark the price conscious consumer could keep her bar stocked with just one or two yearly trips. Calculations of the cost savings associated by going to Denmark to buy alcohol were particularly common in Swedish press around the time of the Danish tax cut of 2003. One example (from the tabloid Expressen, October 20, 2003) claimed that two persons sharing a car from Stockholm (around 600 kilometers from Malmö) and each buying the full quota at the time would save 3200 kronor (around 350 euros).

Our data set allows another opportunity to relate the effects of lower foreign prices to demand in different locations. Historically beer and wine have been cheaper in Sweden than in Finland, while the prices of spirits have been roughly equal in the two countries. ${ }^{16}$ This changed two months before Estonia was due to enter the European Union in May 2004. Finland feared the effects of a very large price

\footnotetext{
${ }^{16}$ In June 1999 for instance a basket of beer (wine) was 13 (19) percent more expensive in Finland than in Sweden, while a basket of spirits was some 2 percent cheaper in Finland (Horverak and Osterberg, 2002).
} 
differential with its neighbor and therefore reduced the spirits tax by 44 percent resulting in a fall of the spirits price index by 38 percent relative to the previous month. This in turn made spirits prices in Finland very attractive to Swedes in the northern parts of the country. ${ }^{17}$ The price indices of wine and beer fell by 7 percent.

In Table 4 we examine the effects on the northern regions. We use the 12month percentage change in sales in the sparsely populated northernmost 34 municipalities (maximum distance to the Finnish border is 742 kilometers). With only five months of data we have essentially no variation in $\Delta_{12} \mathrm{P}^{\mathrm{D}}$ or $\Delta_{12} \mathrm{P}^{\mathrm{F}}$ and we therefore estimate a SUR specification with only a third order polynomial of distance, and the percentage change in the number of Fridays, as independent variables. ${ }^{18}$

While the effects of distance on sales of wine and beer are very marginal, spirits sales are highly sensitive. ${ }^{19}$ For spirits the point estimate suggests that sales at the border municipalities fell by 44 percent relative to the year before. For the five months in question, $\Delta_{12} \mathrm{P}^{\mathrm{F}}$, was about 0.40 which suggest that the cross price elasticity at the border was about unity. Moving 200 kilometers away from the border the elasticity would fall to 0.3 and at 400 kilometers it is around 0.15 . The estimated elasticities at the Finnish border are thus even higher than at the Danish border. This is no doubt due to the fact that there is no direct cost of crossing the Finnish border. For instance, from the single Systembolaget store in the border municipality of Haparanda to the Finnish counterpart (Alko) in Tornio there is only a 10 minute drive, which could definitely be worthwhile even for small purchases. As noted in footnote 9, traveling to Demark by bridge or ferry involves direct costs of at least 500 kronor.

\section{[TABLE 4 ABOUT HERE]}

\footnotetext{
${ }^{17}$ Before the tax cut a liter of Absolute Vodka cost the equivalent of 329 kronor in Finland and after 219 kronor which can be compared to 310 kronor in Sweden.

${ }^{18}$ For spirits, $\Delta_{12} \mathrm{P}^{\mathrm{F}}$ ranged from -0.409 to -0.395 and $\Delta_{12} \mathrm{P}^{\mathrm{D}}$ between -0.001 and -0.014 .

${ }^{19}$ For wine, distance to the border has no significant effect which might be explained by the fact that wine even after the tax cut remained more expensive in Finland. For beer there is a small but statistically significant effect which could potentially also be due to substitution away from domestically sold beer to spirits bought in Finland.
} 


\section{Conclusion}

Many studies have documented deviations from the Law of One Price in international settings. Our analysis of alcohol sales across Swedish regions offers an indication that the magnitude of cross border arbitrage that these deviations give rise to can be substantial. By estimating demand functions we have shown that the sensitivity of regional sales with respect to foreign prices depends on the distance to the border. The estimated elasticities are naturally highest at the communities near the border but the effect lingers several hundred kilometers inland.

From a policy perspective, cross border shopping can have a significant effect on a country's tax revenues. Calls for tax harmonization within the European Union have often been accompanied by references to domino effects ("race to the bottom") of differential alcohol taxation. For instance, Denmark and Finland reduced their taxes with reference to cross border shopping in neighboring countries with low prices (Germany and Estonia, respectively); Sweden is currently contemplating the effects of lowering its taxes to get prices closer in line with its closest neighbors. Our estimates suggest that indeed the consequences for tax revenues are non-trivial. Taking the recent Danish spirits tax cut in October 2003 and making a back of the envelope calculation of the effects on Swedish tax revenues suggest a direct loss of about 214 million kronor (some 24 million euro per year or 2.7 euro per capita). ${ }^{20}$ While the tax revenue implications in general will depend on many factors, these numbers nevertheless suggest that the literature on tax competition between governments (Kanbur and Keen, 1993, Wang, 1999 and Nielsen, 2001), have empirical relevance.

\footnotetext{
${ }^{20} \mathrm{We}$ calculate the percentage fall in sales volume that is implied by estimates in column 2 in Table 2 for each municipality. By multiplying these numbers with municipal population and tax revenue per liter of spirits (201 kronor per liter of spirits and an additional 66 kronor in VAT if we use a medium price brand of spirits as a basis for the VAT calculations) we reach the above number. As a comparison, we estimate that the Finnish tax cut in March 2004, which had an effect primarily on the sparsely populated northern regions, lowered Swedish tax revenues by 21.5 million kronor per year.
} 
Table 1. Change in regional sales volume related to distance to Danish border. Dependent variable is 108-month difference (May 1995 - May2004) in $\log$ of sales volume, $\Delta_{108} \ln \left[\mathrm{q}_{\mathrm{i}, \mathrm{t}}\right]$. Least squares estimation.

\begin{tabular}{llll}
\hline & Spirits $^{\mathrm{a}}$ & Wine $^{\mathrm{a}}$ & Beer $^{\mathrm{a}}$ \\
Dist & $0.943^{* * *}$ & $0.821^{* * *}$ & $0.855^{* * *}$ \\
& {$[0.133]$} & {$[0.163]$} & {$[0.144]$} \\
Dist $^{2}$ & $-0.464^{* * *}$ & $-0.258^{* *}$ & $-0.343^{* * *}$ \\
& {$[0.091]$} & {$[0.107]$} & {$[0.094]$} \\
Constant & $-0.793^{* * *}$ & $-0.093^{*}$ & $0.101^{* *}$ \\
& {$[0.040]$} & {$[0.048]$} & {$[0.040]$} \\
Observations & 233 & 233 & 233 \\
R-squared & 0.32 & 0.30 & 0.24 \\
Test & & & \\
\hline [Robust standard errors $]^{* * * * *}$, and $^{*}$ indicate significance at 1,5, and 10 & percent level, respectively.
\end{tabular}

a) Sample excludes municipalities that border to Norway and Finland.

b) Test is the probability that Dist $=$ Dist $^{2}=0$. 
Table 2. Change in regional sales volume. Dependent variable is 12 -month difference in log of sales volume, $\Delta_{12} \ln \left[\mathrm{q}_{\mathrm{j}, \mathrm{i}, \mathrm{t}}\right]$. Foreign price, $\mathrm{P}^{\mathrm{F}}$, is for Denmark. Seemingly Unrelated Regressions estimation of (2).

\begin{tabular}{|c|c|c|c|c|c|c|}
\hline & $\begin{array}{l}\text { Spirits }^{a} \\
\text { (1) }\end{array}$ & $\begin{array}{l}\text { Spirits }{ }^{b} \\
(2)\end{array}$ & $\begin{array}{l}\text { Wine }^{\mathrm{a}} \\
\text { (3) }\end{array}$ & $\begin{array}{l}\text { Wine } \\
\text { (4) }\end{array}$ & $\begin{array}{l}\text { Beer }^{a} \\
(5)\end{array}$ & $\begin{array}{l}\text { Beer }^{b} \\
(6)\end{array}$ \\
\hline$\Delta_{12} \ln \left[\mathrm{P}^{\mathrm{D}}\right]$ & $\begin{array}{l}-0.784^{* * *} \\
{[0.027]}\end{array}$ & $\begin{array}{l}-0.858^{* * *} \\
{[0.028]}\end{array}$ & $\begin{array}{l}-0.188^{* * *} \\
{[0.015]}\end{array}$ & $\begin{array}{l}-0.237^{* * *} \\
{[0.017]}\end{array}$ & $\begin{array}{l}-0.781^{* * *} \\
{[0.024]}\end{array}$ & $\begin{array}{l}-0.880^{* * *} \\
{[0.029]}\end{array}$ \\
\hline$\Delta_{12} \ln \left[\mathrm{P}^{\mathrm{F}}\right]$ & $\begin{array}{l}0.324^{* * *} \\
{[0.011]}\end{array}$ & $\begin{array}{l}0.400^{* * *} \\
{[0.014]}\end{array}$ & $\begin{array}{l}0.117^{* * *} \\
{[0.025]}\end{array}$ & $\begin{array}{l}0.257^{* * * *} \\
{[0.032]}\end{array}$ & $\begin{array}{l}0.445^{* * *} \\
{[0.035]}\end{array}$ & $\begin{array}{l}0.779^{* * *} \\
{[0.051]}\end{array}$ \\
\hline $\operatorname{Dist} \times \Delta_{12} \ln \left[\mathrm{P}^{\mathrm{F}}\right]$ & $\begin{array}{l}-0.939^{* * *} \\
{[0.069]}\end{array}$ & $\begin{array}{l}-1.342^{* * *} \\
{[0.120]}\end{array}$ & $\begin{array}{l}-0.870^{* * *} \\
{[0.157]}\end{array}$ & $\begin{array}{l}-1.733^{* * *} \\
{[0.289]}\end{array}$ & $\begin{array}{l}-0.951^{* * *} \\
{[0.221]}\end{array}$ & $\begin{array}{l}-2.518^{* * *} \\
{[0.450]}\end{array}$ \\
\hline $\operatorname{Dist}^{2} \times \Delta_{12} \ln \left[\mathrm{P}^{\mathrm{F}}\right]$ & $\begin{array}{l}0.864^{* * *} \\
{[0.122]}\end{array}$ & $\begin{array}{l}1.857^{* * *} \\
{[0.293]}\end{array}$ & $\begin{array}{l}1.172^{* * *} \\
{[0.277]}\end{array}$ & $\begin{array}{l}3.336^{* * *} \\
{[0.710]}\end{array}$ & $\begin{array}{l}0.986^{* *} \\
{[0.390]}\end{array}$ & $\begin{array}{l}4.781^{* * *} \\
{[1.106]}\end{array}$ \\
\hline $\operatorname{Dist}^{3} \times \Delta_{12} \ln \left[\mathrm{P}^{\mathrm{F}}\right]$ & $\begin{array}{l}-0.205^{* * *} \\
{[0.057]}\end{array}$ & $\begin{array}{l}-0.872^{* * *} \\
{[0.205]}\end{array}$ & $\begin{array}{l}-0.490^{* * *} \\
{[0.130]}\end{array}$ & $\begin{array}{l}-2.029^{* * *} \\
{[0.498]}\end{array}$ & $\begin{array}{l}-0.306^{*} \\
{[0.183]}\end{array}$ & $\begin{array}{l}-2.983^{* * *} \\
{[0.778]}\end{array}$ \\
\hline$\Delta_{12} \ln [$ Fridays $]$ & $\begin{array}{l}0.136^{* * *} \\
{[0.005]}\end{array}$ & $\begin{array}{l}0.192^{* * *} \\
{[0.005]}\end{array}$ & $\begin{array}{l}0.196^{* * *} \\
{[0.006]}\end{array}$ & $\begin{array}{l}0.255^{* * *} \\
{[0.006]}\end{array}$ & $\begin{array}{l}0.251^{* * *} \\
{[0.006]}\end{array}$ & $\begin{array}{l}0.293^{* * *} \\
{[0.007]}\end{array}$ \\
\hline Constant & $\begin{array}{l}-0.032^{* * *} \\
{[0.001]}\end{array}$ & $\begin{array}{l}-0.031^{* * *} \\
{[0.001]}\end{array}$ & $\begin{array}{l}0.031^{* * *} \\
{[0.001]}\end{array}$ & $\begin{array}{l}0.028^{* * *} \\
{[0.001]}\end{array}$ & $\begin{array}{l}0.053^{* * *} \\
{[0.001]}\end{array}$ & $\begin{array}{l}0.052^{* * *} \\
{[0.001]}\end{array}$ \\
\hline $\begin{array}{l}\text { Observations } \\
\text { "R2", } \\
\text { Test }^{\mathrm{c}}\end{array}$ & $\begin{array}{l}25603 \\
0.11 \\
0.00\end{array}$ & $\begin{array}{l}19305 \\
0.19 \\
0.00\end{array}$ & $\begin{array}{l}25603 \\
0.06 \\
0.00\end{array}$ & $\begin{array}{l}19305 \\
0.11 \\
0.00\end{array}$ & $\begin{array}{l}25603 \\
0.05 \\
0.00\end{array}$ & $\begin{array}{l}19305 \\
0.08 \\
0.00\end{array}$ \\
\hline
\end{tabular}

[Robust standard errors] ${ }^{* * *},{ }^{* *}$, and ${ }^{*}$ indicate significance at 1,5 , and 10 percent level, respectively.

a) Sample excludes municipalities that border to Norway and Finland.

b) Sample excludes municipalities that border to Norway and Finland and those where Dist $>1.00$ (1000 kilometers), and March and April months.

c) Test is the probability that $\operatorname{Dist} \times \Delta_{12} \ln \left[\mathrm{P}^{\mathrm{F}}\right]=\operatorname{Dist}^{2} \times \Delta_{12} \ln \left[\mathrm{P}^{\mathrm{F}}\right]=\operatorname{Dist}^{3} \times \Delta_{12} \ln \left[\mathrm{P}^{\mathrm{F}}\right]=0$. 
Table 3. Change in regional sales volume. Dependent variable is 12 -month difference in log of sales volume, $\Delta_{12} \ln \left[\mathrm{q}_{\mathrm{j}, \mathrm{i}, \mathrm{t}}\right]$. Foreign price, $\mathrm{P}^{\mathrm{F}}$, is for Germany. Seemingly Unrelated Regressions estimation (2).

\begin{tabular}{lllllll}
\hline & $\begin{array}{l}\text { Spirits }^{\mathrm{a}} \\
(1)\end{array}$ & $\begin{array}{l}\text { Spirits }^{\mathrm{b}} \\
(2)\end{array}$ & $\begin{array}{l}\text { Wine }^{\mathrm{a}} \\
(3)\end{array}$ & $\begin{array}{l}\text { Wine }^{\mathrm{b}} \\
(4)\end{array}$ & $\begin{array}{l}\text { Beer }^{\mathrm{a}} \\
(5)\end{array}$ & $\begin{array}{l}\text { Beer }^{\mathrm{b}} \\
(6)\end{array}$ \\
\hline & & & & & & \\
$\Delta_{12} \ln \left[\mathrm{P}^{\mathrm{D}}\right]$ & $-0.669^{* * *}$ & $-0.677^{* * *}$ & $-0.243^{* * *}$ & $-0.289^{* * *}$ & $-0.804^{* * *}$ & $-0.919^{* * *}$ \\
& {$[0.029]$} & {$[0.031]$} & {$[0.016]$} & {$[0.018]$} & {$[0.023]$} & {$[0.028]$} \\
$\Delta_{12} \ln \left[\mathrm{P}^{\mathrm{F}}\right]$ & $0.381^{* * *}$ & $0.446^{* * *}$ & $0.229^{* * *}$ & $0.341^{* * *}$ & $0.531^{* * *}$ & $0.688^{* * *}$ \\
& {$[0.034]$} & {$[0.039]$} & {$[0.037]$} & {$[0.044]$} & {$[0.041]$} & {$[0.053]$} \\
Dist $\times \Delta_{12} \ln \left[\mathrm{P}^{\mathrm{F}}\right]$ & $-1.466^{* * *}$ & $-1.770^{* * *}$ & $-1.491^{* * * *}$ & $-2.275^{* * *}$ & $-1.411^{* * *}$ & $-1.856^{* * *}$ \\
& {$[0.210]$} & {$[0.344]$} & {$[0.229]$} & {$[0.394]$} & {$[0.260]$} & {$[0.472]$} \\
Dist $^{2} \times \Delta_{12} \ln \left[\mathrm{P}^{\mathrm{F}}\right]$ & $1.861^{* * *}$ & $2.523^{* * *}$ & $2.149^{* * *}$ & $4.018^{* * *}$ & $1.651^{* * *}$ & $2.579^{* *}$ \\
& {$[0.369]$} & {$[0.848]$} & {$[0.403]$} & {$[0.971]$} & {$[0.459]$} & {$[1.162]$} \\
Dist ${ }^{3} \times \Delta_{12} \ln \left[\mathrm{P}^{\mathrm{F}}\right]$ & $-0.676^{* * *}$ & $-1.020^{*}$ & $-0.954^{* * *}$ & $-2.189^{* * *}$ & $-0.640^{* * *}$ & -1.273 \\
& {$[0.174]$} & {$[0.597]$} & {$[0.190]$} & {$[0.682]$} & {$[0.216]$} & {$[0.818]$} \\
$\Delta_{12} \ln [$ Fridays$]$ & $0.132^{* * *}$ & $0.192^{* * *}$ & $0.197^{* * *}$ & $0.255^{* * *}$ & $0.250^{* * *}$ & $0.290^{* * *}$ \\
& {$[0.005]$} & {$[0.005]$} & {$[0.005]$} & {$[0.006]$} & {$[0.006]$} & {$[0.007]$} \\
Constant & $-0.035^{* * *}$ & $-0.035^{* * *}$ & $0.030^{* * *}$ & $0.027^{* * *}$ & $0.053^{* * *}$ & $0.052^{* * *}$ \\
& {$[0.001]$} & {$[0.001]$} & {$[0.001]$} & {$[0.001]$} & {$[0.001]$} & {$[0.001]$} \\
& & & & & & \\
Observations & 25603 & 19305 & 25603 & 19305 & 25603 & 19305 \\
"R2" & 0.06 & 0.10 & 0.07 & 0.11 & 0.07 & 0.10 \\
Test & 0.00 & 0.00 & 0.00 & 0.00 & 0.00 & 0.00 \\
\hline Robust standard errors $]^{* * * * *}$ and ${ }^{*}$ indicate significance at 1,5, and 10 percent level, respectively
\end{tabular}

[Robust standard errors] ${ }^{* * *},{ }^{* *}$, and ${ }^{*}$ indicate significance at 1,5 , and 10 percent level, respectively.

a) Sample excludes municipalities that border to Norway and Finland.

b) Sample excludes municipalities that border to Norway and Finland and those where Dist $>1.00$ (1000 kilometers), and March and April months.

c) Test is the probability that Dist $\times \Delta_{12} \ln \left[\mathrm{P}^{\mathrm{F}}\right]=\operatorname{Dist}^{2} \times \Delta_{12} \ln \left[\mathrm{P}^{\mathrm{F}}\right]=\operatorname{Dist}^{3} \times \Delta_{12} \ln \left[\mathrm{P}^{\mathrm{F}}\right]=0$. 
Table 4. Change in regional sales volume. Dependent variable is 12 -month

difference in log of sales volume, $\Delta_{12} \ln \left[\mathrm{q}_{\mathrm{i}, \mathrm{t}}\right]$ for the period March 2004-July 2004.

Distance is to the Finnish border.

\begin{tabular}{|c|c|c|c|}
\hline & $\begin{array}{l}\text { Spirits } \\
\text { (1) }\end{array}$ & $\begin{array}{l}\text { Wine } \\
\text { (2) }\end{array}$ & $\begin{array}{l}\text { Beer } \\
\text { (3) }\end{array}$ \\
\hline \multirow[t]{2}{*}{ Dist } & $2.72^{* * *}$ & -0.12 & 0.14 \\
\hline & {$[0.46]$} & {$[0.34]$} & {$[0.41]$} \\
\hline \multirow[t]{2}{*}{ Dist $^{2}$} & $-6.01^{* * *}$ & 0.76 & 0.11 \\
\hline & {$[1.32]$} & {$[0.97]$} & [1.17] \\
\hline \multirow[t]{2}{*}{ Dist $^{3}$} & $4.20^{* * * *}$ & -0.85 & -0.32 \\
\hline & [1.11] & {$[0.81]$} & {$[0.98]$} \\
\hline \multirow{2}{*}{$\Delta_{12} \ln [$ Fridays $]$} & 0.05 & -0.03 & -0.01 \\
\hline & {$[0.04]$} & {$[0.02]$} & {$[0.03]$} \\
\hline \multirow[t]{2}{*}{ Constant } & $-0.44^{* * *}$ & -0.01 & -0.01 \\
\hline & [0.05] & {$[0.03]$} & {$[0.04]$} \\
\hline
\end{tabular}

\begin{tabular}{llll} 
Observations & 164 & 164 & 164 \\
\hline Test $^{\mathrm{a}}$ & 0.00 & 0.17 & 0.08 \\
\hline
\end{tabular}

[Robust standard errors] ${ }^{* * * * *}$, and ${ }^{*}$ indicate significance at 1,5 , and 10 percent level, respectively.

a) Test is the probability that Dist $=\operatorname{Dist}^{2}=\operatorname{Dist}^{3}=0$. 
Figure 1. Estimated sources of alcohol consumption and distance to the Danish border from the approximate population center in different Swedish regions in 2003.

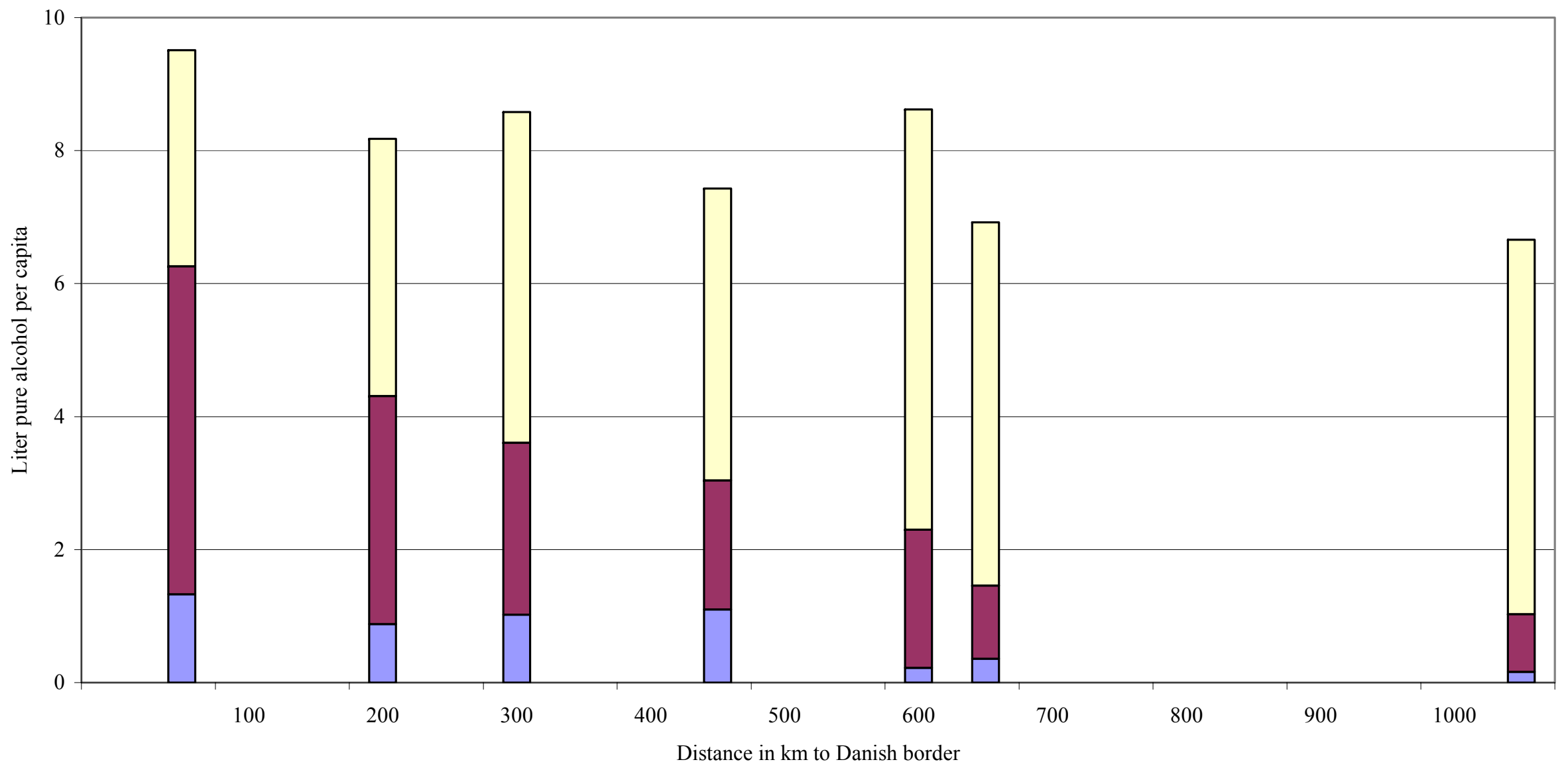

$\square$ Illegal imports $\square$ Legal imports $\square$ Systembolaget 
Figure 2 Map with associated price indices

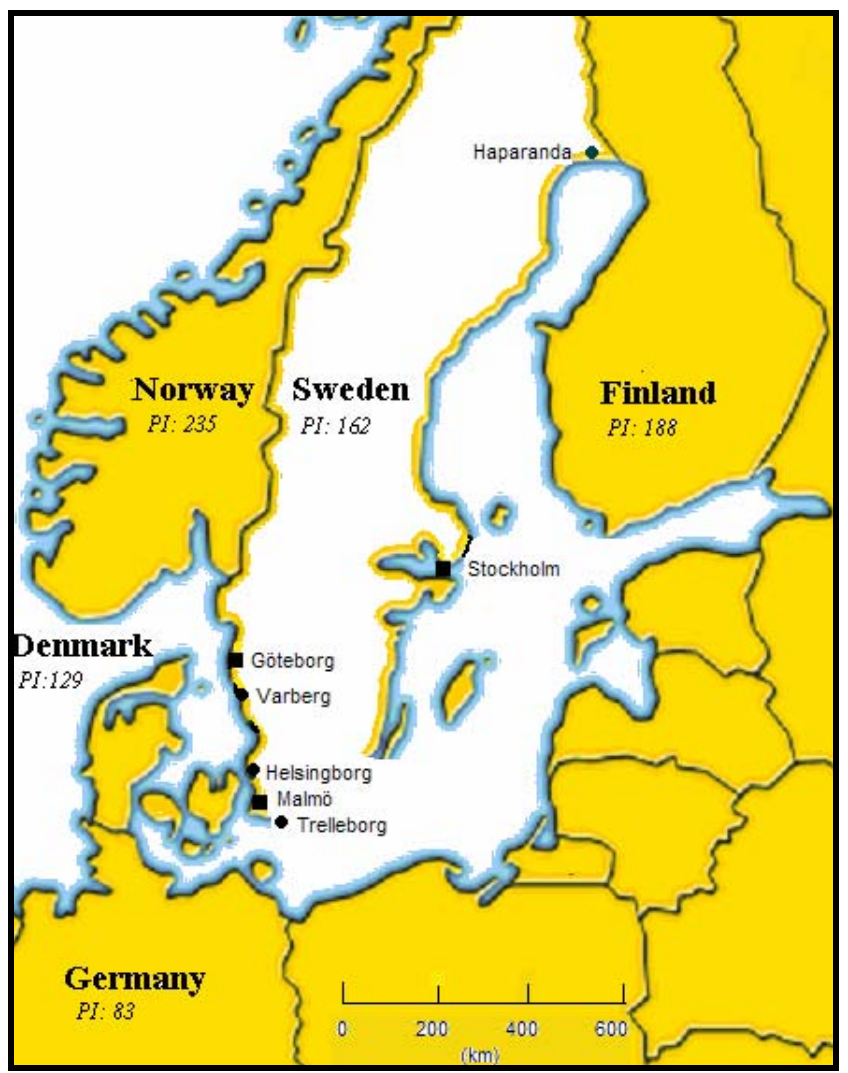

Note: $P I$ is the average alcoholic price index for each country over the period 1995-2003. EU average each year $=100$ 
Figure 3a-3c. Per capita sales and real prices of spirits, wine and beer. Sweden January 1994-July 2004
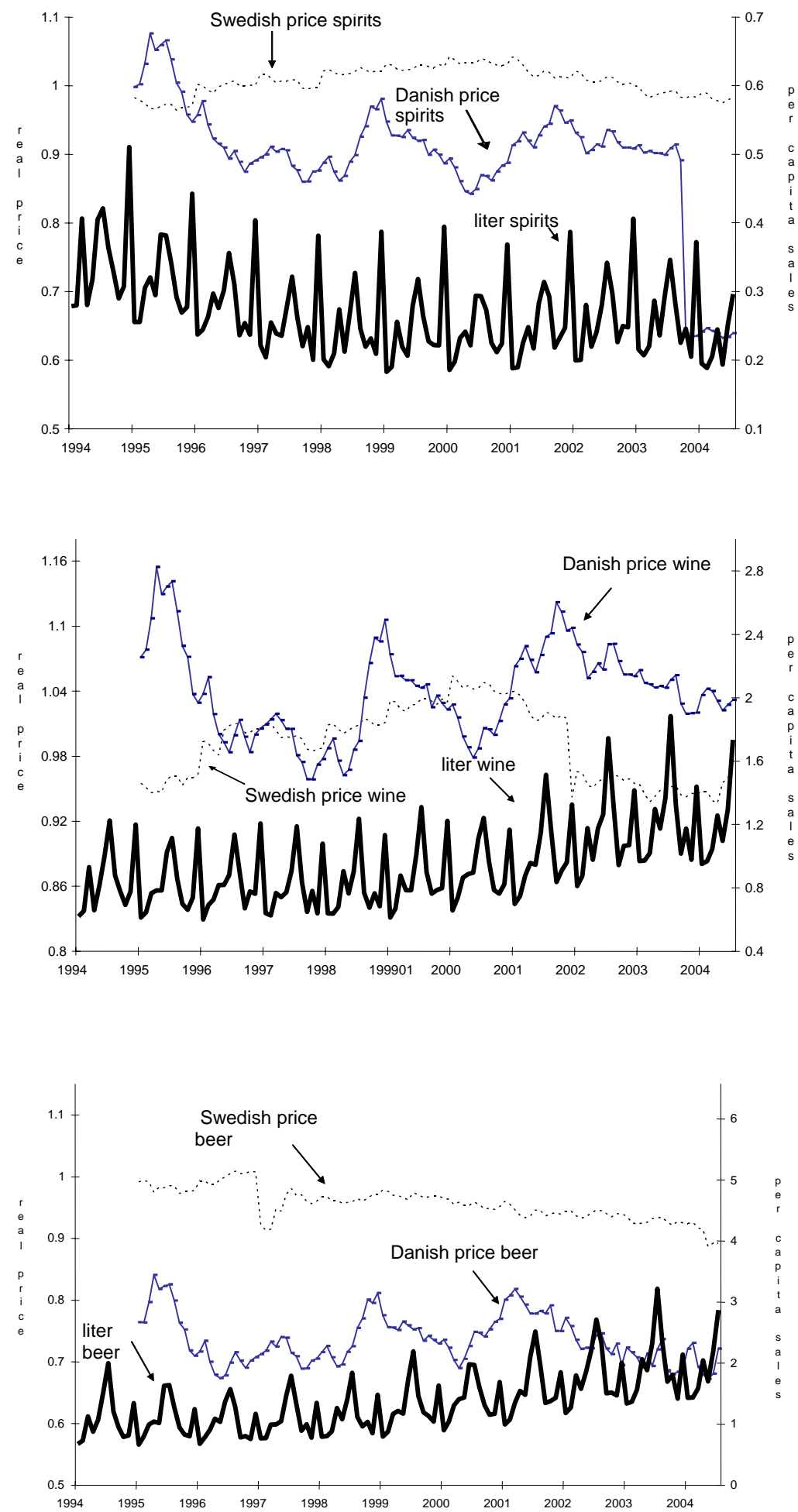
Figure 4. Percentage change in sales per capita, Swedish municipalities May 1995-May 2004

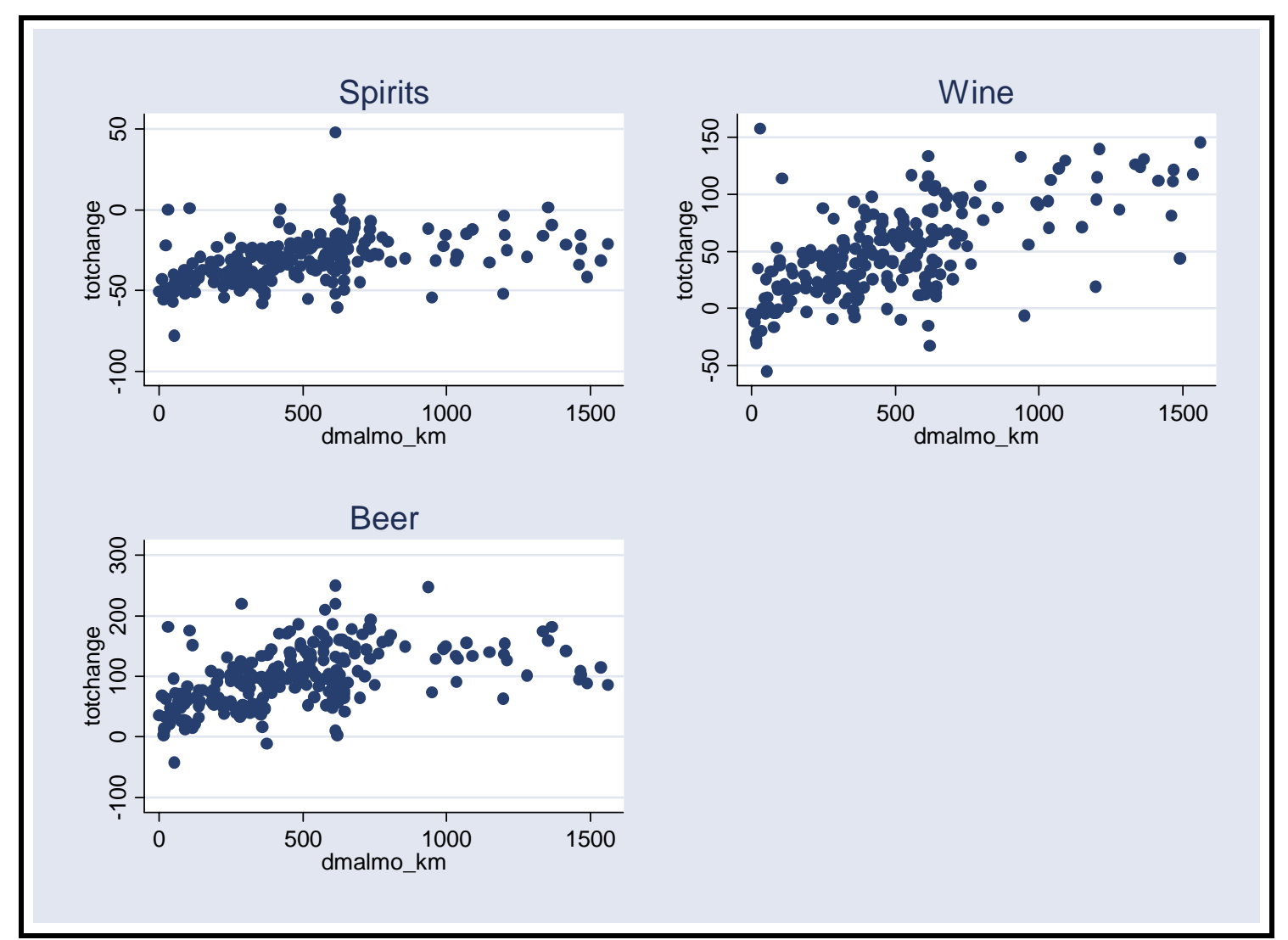


Figure 5a-5c. Estimated effect on sales volumes for spirits, wine and beer in Swedish regions following a $10 \%$ reduction in the corresponding Danish price.
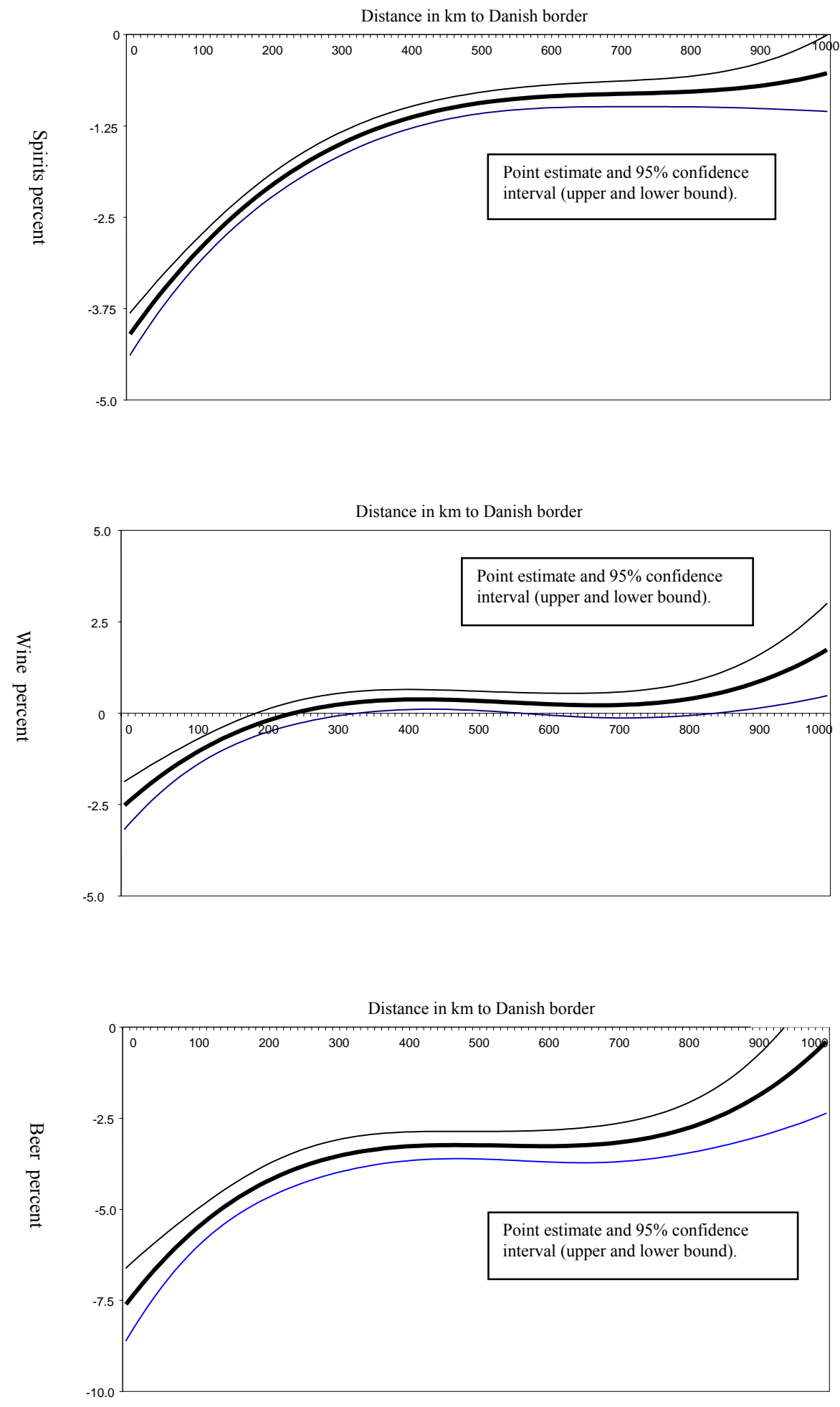


\section{References}

Anderson, James and Eric Van Wincoop (2004), "Trade costs", Journal of Economic Literature 42, 691-751.

Beard, T. Randolph, Paula A. Gant and Richard P. Saba (1997), "Border-crossing sales, tax avoidance, and state tax policies: An application to alcohol", Southern Economic Journal 64, 293-306.

Campbell, Jeffrey R. and Beverly Lapham (2004), "Real exchange rate fluctuations and the dynamics of retail trade industries on the U.S.-Canada border", American Economic Review 94, 1194- 1206.

Commission (2004), "Report from the Commission to the Council, The European Parliament and the European Economic and Social Committee on the rates of excise duty applied on alcohol and alcoholic beverages", available at http://europa.eu.int/eurlex/en/com/rpt/2004/com2004_0223en01.pdf

Engel, Charles and John Rogers (1996), "How wide is the border", American Economic Review 86, 1112-1126.

FitzGerald, John D. (1992), "The distortionary effects of taxes on trade in border areas: the Republic of Ireland-UK border.” In Georg Winckler (ed.), Tax Harmonization andFinancial Liberalization in Europe. New York: St. Martin's Press.

Fox, William F. (1986), "Tax structure and the location of economic activity along state borders", National Tax Journal 39, 387-401.

Ford, Theresa (1992), "International outshopping along the Canada-United States border: The case of western New York", Working paper, Canada-United States Trade Center at the State University of New York at Buffalo.

Garrett, Thomas A. and Thomas L. Marsh (2002), "The revenue impacts of cross border lottery shopping in the presence of spatial autocorrelation", Regional Science and Urban Economics 32, 501-519.

Goldberg, Penelopi K. and Michael M. Knetter (1997), "Goods prices and exchange rates: What have we learned?”, Journal of Economic Literature, 1243-1272.

Goldberg, Penelopi K. and Frank Verboven (2005), "Market integration and convergence to the law of one price: evidence from the European car market," Journal of International Economics 65, 49-73.

Goolsbee, Austan (2000), "In a world without borders: The impact of taxes on Internet Commerce", Quarterly Journal of Economics 115, 561-576.

Haskel, Johnathan and Holger Wolf (2001), "The law of one price - a case study", Scandinavian Journal of Economics 103, 545-559. 
Horverak, Oyvind and Esa Österberg (2002), "Utviklingen i avgifter og priser på alkoholdrikker i Norden på 1990-tallet", Nordisk Alkohol \& Narkotikatidskrift 19, 91-105. [In Norwegian: The development of tariffs and prices of alholic beverages in Nordic countries in the 1990s].

Kanbur, Ravi and Michael Keen (1993), "Jeux sans frontières: Tax competition and tax coordination when countries differ in size", American Economic Review 83, 977 892.

Keen, Michael (2002), "Some international issues in commodity taxation", IMF Working paper 02/124.

Mintz, Jack and Henry Tulkens (1986), "Commodity tax competition between member states of a federation: equilibrium and efficiency," Journal of Public Economics 29, 133-172.

Nielsen, Soren B. (2001), "A Simple Model of Commodity Taxation and Crossborder Shopping”, Scandinavian Journal of Economics 103, 599-624.

Pinkse, Joris, Margaret E. Slade, and Craig Brett (2002), "Spatial price competition: A semiparametric approach”, Econometrica 70, 1111-1153.

SoRAD (2004), "Tabellredovisning av svenska folkets alkoholvanor 2003", [In Swedish: Tables of the alcohol habits of the Swedish people 2003], Stockholm.

SOU (2004), "Var går gränsen?", delbetänkande av alkoholinförselutredningen, SOU 2004:86, Finansdepartementet, Stockholm [In Swedish: Where is the border? Report from the governmental commission on imports of alcohol, Ministry of Finance, Stockholm].

Wang, You-Qiang (1999), "Commodity taxes under fiscal competition: Stackelberg equilibrium and optimality", American Economic Review 89, 974-981.

Walsh, Michael J. and Johnathan D. Jones (1988), "More evidence on the "border tax" effect: The case of West Virginia, 1979-84", National Tax Journal 41, 261-265. 